\title{
SMART SUSTAINABLE ISLANDS VS SMART SUSTAINABLE CITIES
}

\author{
Dimos N. Pantazis ${ }^{1} *$, Vassilios C. Moussas ${ }^{1}$, Beniamino Murgante ${ }^{2}$, Anna Christina Daverona ${ }^{1}$, Panagiotis Stratakis ${ }^{1}$, Nikolaos \\ Vlissidis $^{1}$, Antonis Kavadias ${ }^{1}$, Dimitra Economou ${ }^{1}$, Kostas Santimpantakis ${ }^{1}$, Babis Karathanasis ${ }^{1}$, Vasiliki Kyriakopoulou ${ }^{1}$, Eleni \\ Gadolou $^{1}$ \\ ${ }^{1}$ Research Group SOCRATES (Society for Organizations, Cartography, Remote sensing/Road design and Applications using \\ Technology/Transport engineering on Earth and Space), Dept. of Civil, Surveying and Geoinformatics Engineering, School of \\ Technological Applications, Athens University of Applied Sciences (TEI of Athens), Greece - *dnpantaz@otenet.gr, \\ ${ }^{2}$ School of Engineering, University of Basilicata, Italy
}

KEYWORDS: Smart Sustainable Cities, Smart Sustainable Islands, Island's Smartification, Sustainability Index, Territorial Intelligence, European Island's Sustainability and Smartification Observatory, Smart Islands Initiative, SSI, $\mathrm{S}^{2} \mathrm{I}^{2}$, Intelligent Island

\begin{abstract}
:
This paper has several aims: a) the presentation of a critical analysis of the terms "smart sustainable cities" and "smart sustainable islands" b) the presentation of a number of principles towards to the development methodological framework of concepts and actions, in a form of a manual and actions guide, for the smartification and sustainability of islands. This kind of master plan is divided in thematic sectors (key factors) which concern the insular municipalities c) the creation of an island's smartification and sustainability index d) the first steps towards the creation of a portal for the presentation of our smartification actions manual, together with relative resources, smart applications examples, and, in the near future the first results of our index application in a number of Greek islands and e) the presentation of some proposals of possible actions towards their sustainable development and smartification for the municipalities - islands of Paros and Antiparos in Greece, as case studies.
\end{abstract}

\section{INTRODUCTION}

The term "smart city" is widely used in our days. This paper has several aims: a) a critical analysis of the terms "smart sustainable cities" and "smart sustainable islands" trying to give a more rigorous content in the second (smart sustainable islands) b) the presentation of a methodological framework of concepts and actions, in a form of a manual and actions guide, towards the smartification and sustainability of islands. This kind of "smartification" and "sustainability's" master plan is divided in thematic sectors (key factors) which concern the insular municipalities (words and terms like Manual, Roadmap, How to, Protocol, Guidelines, Master plan for smart sustainable islands, or smart green islands may equally been used to describe our final result) c) the creation of an island's smartification and sustainability index d) the first steps towards the creation of a portal for the presentation/publication of our actions manual (in order to give the insular municipalities a "start point" for their smartification process) as well as all relative resources and smart applications/solutions examples. Our intention for the above mentioned portal is to become a meta-portal containing all relative information about the smart sustainable islands, and, a sort of European observatory of the smartification and sustainability of the European islands using the proposed and/or other index systems and supporting the EU initiative "smart islands" e) the presentation of some proposals of possible actions in the municipalities-islands of Paros and Antiparos, concerning their sustainability and smartification. Although the term "smartification" refers to the same techniques, results, concepts, software, data etc. applied to cities or islands, their application in the smartification process may be quite different when applied in an island. That is, a set of cities/villages closely related and somehow isolated from the rest of the world (connected only via coastal/sea and air routes) and, maybe, surrounded by a cleaner "blue" sea, are somehow "different" from a city. We will try to identify and explain this

* Corresponding Author difference between smartification in a city and in an island. We are also dealing with some questions like: Can an island be considered as one big (distributed) city instead of a set of smaller towns? Is it better/convenient or it is too complex to conceive/implement smartification and sustainability's solution in an entire island? Our motivation for this project mainly concerns the identification and analysis of the differences between the methodologies and actions for cities and islands smartification. Last but not least we mention that our project is in the same line with the EU initiative "smart islands initiative" (EU, 2017): "The Smart Islands Initiative is a bottom-up effort of European island authorities and communities. It builds on years of collaboration between European islands and seeks to communicate the significant potential of islands to function as laboratories for technological, social, environmental, economic and political innovation. The Smart Islands Initiative is inspired by the Smart Cities and Communities - it seeks to improve life on islands through sustainable, integrated solutions that make the most out of islands' competitive advantages. More so, the Smart Islands Initiative underscores the role of islands in accelerating Europe's transition into a low carbon, sustainable and economy." The paper is organized as follows: after a short introduction presenting the paper's goals, the third section presents a literature review of the terms "smart city" and "smart sustainable city" (and similar terms) including some new parameters together with some questions on their use. This section presents the literature review of the terms "Smart Island" and "smart sustainable island" (and similar terms). The forth section presents the principles of an "actions manual" for island municipalities as a start point in their efforts and process to achieve a certain degree of smartification and sustainability in their development. The fifth paragraph gives the basic parameters and the concepts for the creation of a smartification's and sustainability's index specific for islands. The sixth paragraph presents some proposals towards sustainability and smartification actions in Paros and Antiparos islands in the frame of two bilateral cooperation agreements signed by the Research Laboratory S.O.C.R.A.T.E.S. and the two municipalities for technical, educational, scientific and 
research collaboration. The seventh paragraph presents the under construction portal in which will be presented a) the island smartification guide (basic principles), b) the proposed "new" island smartification's and sustainability's actions index together with other index and Finally, conclusions and the future steps of our project financed partially by the Athens University of Applied Sciences (TEI of Athens) and the Research Laboratory S.O.C.R.A.T.E.S. are presented in paragraph nine.

\section{FROM SMART SUSTAINABLE CITIES TO SMART SYSTAINABLE ISLANDS - LITERATURE REVIEW \& NEW PARAMETERS}

The concept "Smart City" is something relatively new in the scientific literature. It has been emerged, more or less, the last two decades (Albino, 2015) and it deals mostly with the economic and social aspects of a city in a sustainable urban environment (Winters, 2011; Manville, 2014). As a concept, it has been proliferated in many different sectors of a city, which has led to different definitions of it, with the term "smart" to be often substituted with other terms such as "intelligent" or "digital". Other terms that have been used for similar concepts include: teritorial intelligence (Bertacchini 2007), cyberville, digital city, electronic communities, information city, intelligent city, knowledge-based city, MESH city, telecity, teletopia, Ubiquitous city, wired city. Nevertheless, the term "Smart" has dominated among the others. Terms like "smart citizen", "smart policy", "smart networks", "smart buses" etc., which are more and more used in any city's aspect, indicates the wide employment of the Smart City concept that happen nowadays.

Actually the term Smart City is sometimes identical with everything that has to do with ICT applications, networks, transportation and generally technological implementations. Even though some authors' state that Smart City rather not be considered limited to these applications (Albino, 2015). Urban policies, spatial planning, city strategic programs of a city are a few key factors that Public Agencies or Municipal Authorities, develop targeting to the smartness of the city and focusing to the people's and societies' needs. Smart City should respond to their citizens needs through sustainable solutions. Based on this argument and relation between the two terms, "smart" and "sustainability", has been created and used in the literature the combined term "Smart Sustainable Cities". Cities nowadays, have problems and it is expected to will have the same or even new in the future. Thus seeking ways to "smart" manage these problems and look for "smart" solutions is a key factor for a "smart" city "growth" (not only in economic terms). A smart city can also be defined as a city overlaid by a digital layer, which is used not only for storing city information but for its overall governance. A smart city cannot be defined without a greater involvement of citizens (smart people) (UDMS, 2017).

A number of topics related with the "smart city" term are also mentioned in the relative literature, such as: smart data (Sensor network databases, On-the-fly data mining, geographic and urban knowledge modeling and engineering, green computing, urban data analytics and big data, big databases and data management (NoSQL), smart people (Volunteered information, Systems for public participation), Systems of territorial intelligence, Systems for city intelligent management in the fields such as building, transportation, energy, 3D modeling of cities, internet of things, social networks, monitoring systems, mobility and transportation, smart-city-wide telecommunications infrastructure, urban knowledge engineering, urban dashboard design and implementation, new style of urban decision-making systems, geovisualization devoted to urban problems, disaster management systems (UDMS, 2017). Some basic questions, that the term "smart city" produces, may be: How do cities become smart, and, how do we define the Smart-ness and their smartification? What really makes a city smart? What could be the target, the cost and the benefits of a "smartification process"? How easy is to realize a cost benefits analysis of a smartification process? Is it better to connect the term "smart city" with only technological parameters and topics such as database, sensors, apps etc., or, with thematic sectors such as transport, environment, economy, energy, etc.? A straightforward correspondence between humans and cities regarding the term "smart" is also observed. "Smart" for humans includes three major stages: Feel-Think-React. "Smart" for cities also includes three stages: Monitoring-ProcessingControl/Act. For example, smart cities should develop monitoring, analysis \& reaction mechanisms to prevent: pollution, accidents, energy loss, flood, black-outs, tsunami, traffic jam, smog, water shortage, etc. According to another current definition, a "smart city" is an urban development vision to integrate multiple Information and Communication Technology (ICT) and Internet of Things (IoT) solutions in a secure fashion to manage a city's assets, and, the goal of building a "smart city" is to improve quality of life, to improve the efficiency of services and to meet residents' needs. (Musa 2016). Are the above definitions complete? Is "Smart cities" a "static" term? According to the "Smart Cities" background paper of DBIS (2013), the concept is not static, there is no absolute definition of a "smart city", no end point, but rather a process, or series of steps, by which cities become more "liveable" and resilient and, hence, able to respond quicklier to new challenges. In any case, we consider that the term "smart city" does not cover all the aspects that the "ideal" future city (if such a thing exists) must inlude potical, socieconomic, human and ethical parameters. Trying to enrich the term "smart city" in the frame of our project we are looking in the term "green". According to a current definition a "green city" or a sustainable city, or eco-city (also "ecocity") is a city designed with consideration of environmental impact, inhabited by people dedicated towards minimization of required inputs of energy, water and food, and waste output of heat, air pollution $-\mathrm{CO}_{2}$, methane, and water pollution (Lehmann, 2010). Minimally, a sustainable city should firstly be able to feed itself with a sustainable reliance on the surrounding countryside (or seaside). Secondly, it should be able to power itself with renewable sources of energy. The crux of this is to create the smallest possible ecological footprint (i.e., to produce the lowest possible quantity of pollution, to efficiently use land (or sea), compost used materials, recycle it or convert waste-to-energy, etc.). Key achievements of a "green city" include: renewable energy, natural ventilation, improved/sustainable public tranport, green roofs, sustainable urban drainage systems, recycling, urban farming, individual buildings (LEED certified sustainability), zero-energy buildings. Blue-Green Cities (BGC) aim to recreate a naturally oriented water cycle while contributing to the amenity of the city by bringing water management and green infrastructure together (BGC, 2016). Designing and utilising the urban environment to manage water resources, water demand (including rainwater harvesting), and the interplay between flood and drought are key drivers. It turns out that "Smart" \& "Green" together lead to sustainability (Woodrow, 2016). Another relevant term is Smart Green Resilient (SGR): The SGR planning approach is based on observations of East Asia's rapid urbanisation processes that have left many cities and landscapes in the region vulnerable to climate change, environmental degradation and socioeconomic fluctuations (Chong, 2014). In addition to the definitions, building "Smart Green Cities" requires also the development of future 
plans/frameworks presenting the necessary steps that will improve: energy use, communication, collaboration, resilience on infrastructure, etc. (DNVGL, 2017). We conclude this with the following remarks: a) a smart city may not be a sustainable city (e.g. short term vision in the proposed "smart solutions" b) a sustainable city may not be a smart city (e.g. The sustainability achieved without the smart solutions) c) sometimes smartification and sustainability are contradictory forces which must conciliate d) the smartification of a city does not concern only the informatization of a number of procedures but rather the smart solution to specific problems.

The term "Smart Island" appears in the project "Smart Web services for Mediterranean Islands" (GISIG, 2014) as: "Smart Islands is an integration platform developed through the ICT PSP call. When finalized it will provide to the users a variety of standardized web services under a friendly $3 D$ interface like Google Earth developed specifically for this purpose. The web services will cover various aspects of everyday life such as Civil Protection, Environment, Forest Fires Simulation and Management, Tourism, Retail Operations, Marketing, Statistics, Education, Virtual Tour, Real Time Weather Forecasting, Transportation, Yachting Services etc. The platform will be open-ended. The API will be made available to the developers' community giving the ability to develop additional web services following standardized procedures as described by OGC." The term was also used in the context of the development of a Smart-Islands Platform for the tourism support (Di Staso et. al, 2014). The "Smart Islands" project is the continuation of the European Economic and Social Committee's (EESC) owninitiative opinion on Smart Islands. The project aims to engage and exchange with local stakeholders on innovative projects developed locally, which create sustainable growth and, at the same time, job opportunities and competiveness, whilst respecting the environment and cultural heritage (EU, 2015). As an outcome of the project, a catalogue of good practices is going to be published. In 2015 and 2016, a delegation of EESC Members carried out fact-finding missions to six EU islands that are implementing remarkable projects, in order to meet with local stakeholders, as well as, to visit projects implemented in the islands. In another EE-Spanish government project (Deign, 2016) the term has been used for the touristic Balearic and Canary Islands, and the objective is "...to finance initiatives that integrate smart island strategies, contribute to the improvement of public services in the territory, and are aimed at mitigating the negative effects of insularity through the use of information and communications technology (ITC)". Nevertheless, as also mentioned in (Deign, 2016), "...while the exact nature of the smart-island applications that will be developed has yet to be revealed, what is seems likely is that much of the investment be related to tourism". Another relevant work is also found in "Smart Islands Projects and Strategies" (Efthymiopoulos, 2016) a documentation of smart projects and strategies implemented by over 30 European islands across 13 European countries. The publication presents lighthouse projects from: Croatia, Cyprus, Denmark, Finland, France, Germany, Greece, Italy, Malta, Netherlands, Spain, Sweden, United Kingdom, currently under implementation or in the phase of maturation, which were showcased during the 1st Smart Islands Forum. The report presents the profiles of most of the European islands involved in climate responsible and innovative projects, providing also an overview of the technologies deployed. In this work it is mentioned that: "The Smart Islands Initiative is the culmination of a series of activities, among which stands prominently the Pact of Islands. The Pact of Islands is a political scheme engaging islands to go beyond the EU 2020 climate and energy targets, counting today
117 signatories across Europe". The term also appears in (CNR 2016) as a project title in the island of Lampedusa. The ultimate goal of the project is the transformation of the island of Lampedusa into an innovative model of Smart Island.

The term smart sustainable island, in our context, has the same meaning with the term smart sustainable city, but in addition: 1) it refers to the entire region of an island and not to a specific city 2) the term "sustainable" means that the entire island follows all the good practices to preserve the sustainable development and the protection of the environment, natural and urban, including the culture heritage in a holistic and integrated manner. We note here that an island constitutes an autonomous entity that must be seen and considered in a holistic way. Its "smartification" should not concern just a city or a village but the entire island. The particularities of the smartification of an island are related with its geographic characteristics, the isolation, the coastal lines, the tourism, the medical care, the infrastructure, the transport of goods, the education, the limited economic possibilities, etc. Finally, we thing that may be it is interesting to also investigate the Russian puppets schema of the smartification process i.e.: from the inner to the outer components, e.g. smart home $\rightarrow$ smart city $\rightarrow$ smart island $\rightarrow$ smart region $\rightarrow$ smart country $\rightarrow$ smart world.

\section{SMART SUSTAINABLE ISLANDS. AN ACTIONS - ROADMAP MANUAL TOWARDS THE ISLAND'S SUSTAINABLE SMARTIFICATION}

According to the EU initiative "Smart Islands", "[...] a smart island is the insular territory that embarks on a climate resilient pathway, combining climate change mitigation and adaptation efforts, in order to create sustainable local economic development and a high quality of life for the local population by implementing smart and integrated solutions to the management of infrastructures, natural resources and the environment as a whole, supported by the use of ICT, all while promoting the use of innovative and socially inclusive governance and financing schemes". The term "Smart Green Islands" (SGI) is also used instead of the SSI (Smart Sustainable Islands), with a slightly different content (AMK, 2016) and (Stetter, 2016).

In our proposal we follow the EU initiative "smart island" key factors: energy, transport, water, waste, governance, ICT and economy, in order to develop a sort of guidelines and a start point for island's sustainable smartification. Some special key factors may be added in some islands. We call them "Special Key Factors - SKF", e.g. Refugees. The actions guide or road map we develop will help an insular municipality to: a) prioritize its actions and projects for smartification, b) choose and deliver innovative technological solutions providing a stepped approach to getting "smarter" with two options: 1) under a holistic and integrated platform, or, 2) as isolated applications and projects. For example regarding Energy, "smarter" means improving performance, reliability, controllability, thus moving to a smarter grid that will reduce emissions by allowing greater integration of renewable, more efficient use of the energy they produce, integration of smart vehicles and promote cleaner transport introduction of demand response mechanisms to reduce energy demand. According to Musa (2016) a "smart city" roadmap consists of the following major components:

1. Define exactly what is the community: (geography, links between cities and countryside, flows of people between them, definition of City/community). 
2. Study the Community: (know the citizens, the business' needs, the community's unique attributes, age, education, hobbies, and attractions of the area).

3. Develop a Smart City Policy: Develop a policy to drive the initiatives, where roles, responsibilities, objective, and goals, can be defined. Create plans and strategies on how the goals will be achieved.

4. Engage the Citizens: (through the use of e-government initiatives, open data, sport events, etc.)

The road map should provide answers to questions like: What is the list of achievements that will define a sustainable island? What is the list of achievements that will define an island as "smart"? What is the list of combined achievements that will define an island as "sustainable and smart"? How to reduce the island-mainland isolation (smarter \& sustainable connections)? How to improve an island's everyday life (smarter \& sustainable everyday tasks/tools)? How they can attract new people and resources in the island to support this effort? How they will benefit by being Smart \& Sustainable? What can be defined as a sustainable and smart Investment? How tourism can be defined as smart and sustainable in the islands? Which could be the Smart and Sustainable local production that will offer more independence from mainland?

Another important point in our approach, as already said, is the fact that we do not necessarily connect the smartification with the informatization or the advance in technology. In fact the informatization not accompanied by the solution of a problem will just informatize the problem without solving it. That is why the solution must always be the first step. As a consequence, in our approach, the smartification means "smart" solution at any problem without necessarily using technologically advanced equipment and/or software. The management of a municipality divided in different sectors. In Greece and other countries does not exist the same administrative structure for each municipality. In our case, we decided to follow the key factors proposed by the EU initiative "smart islands" for the development of a road map of actions towards the smartification of an island. We have classified in those key factors a number of a) tools, b) applications, c) procedures d) smart applications e) examples and f) practices that may be used in the frame of a smartification process, such as: -The Geographic Information System (GIS) of the municipality connected or integrated with the Information System of the municipality-The municipal vehicles fleet navigation tools-The management of the municipal property- The water supply management- The sewerage management- The environmental management- The municipal lights management- The municipal roads network management- The management of the municipal local marketsThe cultural and sport event management- The schools infrastructure management- The municipal image on the internet, communication and public relations- The municipal egovernment- The telemedicine applications- The paperless office environment- Smart energy management- Smart applications with drones- Smart applications with sensors- The information and data management concerning the tourists-The information and data management concerning the coastal linesSmart applications for the municipal police- Special applications (e.g. refugees management). Smart consumption (of energy, food, products) by citizens, enterprises, public services. Smart solutions for a sustainable economy and not for a continuing economic growth. Each of those key factors constitutes a chapter in the actions guide/roadmap under development: "Towards to a smart sustainable Island: A guide for actions". Each chapter has the same structure. We analyze the basic concepts, we give specific examples, we present some technological solutions and tools concerning the software and hardware, and finally we underline the parameters to take into consideration for a cost-benefit analysis. The proposed roadmap will be developed in collaboration with two municipalities (Paros, Antiparos) in order to be used as an actions guide for any insular municipality and its final version will be published in our web site/portal that is under construction.

\section{S.O.C.R.A.T.E.S $S^{2} I^{2}$ : AN INDEX FOR ISLANDS' SMARTIFICATION AND SUSTAINABILITY}

The key characteristics of a "smart city" should include: smart energy/environment, smart transport/mobility, smart economy, smart building/ infrastructure, smart technology/comms, smart healthcare/safety, smart people/citizen, smart living, smart governance, (IEEE, 2017), (BD, 2017) and (Sarwant, 2014). For the city of New York (NYC, 2015) the road to a "smarter" city included several plans for smarter: indoor lighting, traffic management, waste management, air quality monitoring, gunshot detection, snow plow tracking, etc. The creation of an island smartification and sustainability index (Smart Sustainable Island Index or $\mathrm{S}^{2} \mathrm{I}^{2}$ ) is one of the main targets of our project. The utility of such an index is the quantification of the achievement of each insular municipality towards its smartification. The smartification index may also play the role of an alarm for the municipality for the increasing number of problems lacking smart solutions. Concerning the specific index we must take into consideration the following parameters: a) the number of sectors affected by the "smart" solutions b) the number of smart solutions available for each sector c) the percentage of the island's surface that is affected d) the number of people that will benefit by the solution/application e) the influence in the wellbeing of citizens and visitors (trying to take in consideration not only parameters which are related to the PNB but also factors related to the overall happiness of people) f) the number of unsolved problems in the island and the area \& population affected, as well as, the time that they still remain unsolved g) the duration and the long term vision of a smart solution, or in other words, the resilience and the sustainability of a proposed smart solution. The $\mathrm{S}^{2} \mathrm{I}^{2}$ index may also be used to measure the efficiency of the local authorities. The typical term used for this type of indices or indicators is Key Performance Index (KPI), as for instance the KPI for Smart Sustainable (green) Cities (ITU, 2015) and (Sanseverino, 2016). A sample list of applications, needs, or, actions that lead to a more smart and sustainable city or island is shown in Table 1.

\begin{tabular}{|cl|}
\hline $\begin{array}{c}\text { Smartification and sustainability's proccess: } \\
\text { Sample applications and needs }\end{array}$ \\
\hline 1. & Smart Data (need for) \\
2. & Next genetation networks \\
3. & Smart mobility \\
4. & Smart lights \\
5. & Energy efficiency / independency \\
6. & Green builidngs \\
7. & Zero emmisions \\
8. & Smart parking \\
9. & Smart transorts \\
10. & Urban areas exploitiation \\
11. & Smart citizens \\
12. & E-government \\
13. & Open gov \\
14. & Smart wastes \\
\hline Table 1. Smartification and sustainability's
\end{tabular}

proccess: Sample applications and needs

In the rest of this section, a Key Performance Index (KPI) for Smart Sustainable Islands (SSI) is compiled for the classification and appraisal of an island in terms of smartness 
and sustainability. Typically, a KPI consists of several Performance Indicators (PI) each composed by Sub-Indicators and by simpler Measured Values (MV) often called Metrics. The development of an index system for SSI is partially based on the results of a comparative study \& analysis from the International Telecommunication Union (ITU) on existing index systems developed worldwide for Smart Sustainable Cities (SSC) (ITU, 2015). More than 15 indexing systems were studied such as: ISO, ITU, UN-Habitat, China's CIC \& MOHURD, EU, Italy's EY, Japan TTC, GCIF, ICLEI, ESCI, Vienna UoT, Leibnitz Inst., Ericsson, IBM, IDC Spain, PwC, Siemens. The major part of the ITU index system (ITU 2016) is adopted, with some minor changes or adjustments. Another part was also developed and appended to it, in order to build the proposed Smart Sustainable Islands indexing $\left(\mathrm{S}^{2} \mathrm{I}^{2}\right)$ system, that will incorporate all island particularities presented in the previous section. The resulting SSI index system is dercribed below.

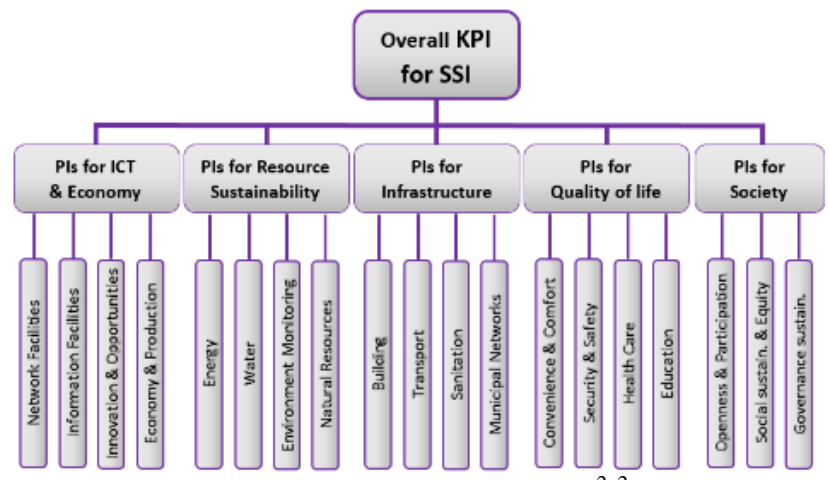

Figure 1: The structure of the Proposed $\mathrm{S}^{2} \mathrm{I}^{2}$ scheme

The overall KPI (Figure 1) is composed of 5 main Dimensions (PIs), namely:

1. ICT \& Economy

2. Resource Sustainability

3. Infrastructure

4. Quality of life

5. Society

Each PI is composed of a number of sub-dimensions as shown in table 2. Each sub-dimension is subsequently composed of a number of basic indicators that must be measurable (MVs or metrics) as shown in table 3 .

\begin{tabular}{|l|l|}
\hline \multicolumn{1}{|c|}{ Dimension } & \multicolumn{1}{c|}{ Sub-Dimensions } \\
\hline $\begin{array}{l}\text { ICT \& } \\
\text { Economy }\end{array}$ & $\begin{array}{l}\text { Network Facilities, Information Facilities, Innovation \& } \\
\text { Opportunities, Economic sustainability, Island } \\
\text { Productivity, Tourism }\end{array}$ \\
\hline $\begin{array}{l}\text { Resource(Env.) } \\
\text { Sustainability }\end{array}$ & $\begin{array}{l}\text { Energy, Water Natural Resources, Environmental } \\
\text { monitoring \& sustainability, }\end{array}$ \\
\hline Infrastructure & $\begin{array}{l}\text { Building, Transport, Sanitation, Municipal pipe networks, } \\
\text { Recycling infrastructures }\end{array}$ \\
\hline Quality of life & $\begin{array}{l}\text { Convenience \& Comfort, Security \& Safety, Health care, } \\
\text { Education }\end{array}$ \\
\hline Society & $\begin{array}{l}\text { Openness \& public partitipation, Social sustainability \& } \\
\text { equity, Governance sustainability }\end{array}$ \\
\hline
\end{tabular}

Table 2. Main dimensions and sub-dimensions of the proposed KPI scheme for Smart Sustainable Islands Index $\left(\mathrm{S}^{2} \mathrm{I}^{2}\right)$

The proposed $\mathrm{S}^{2} \mathrm{I}^{2}$ scheme is summarized in Figure 2 . Aggregation of the metrics for comparisons between islands requires the standasdization of their values. A method is to transform all indicator values $x_{i}$ to the corresponding normal distribution z-value with an average of 0 and a standard deviation of 1 using the formula: $z_{i}=\left(x_{i}-x_{\text {mean }}\right) / s$, (TUW, 2017). Proper weighting of the above criteria is also required and must be defined for the Smart Sustainable Island case. The weighting coefficients values are set equal to 1 , by default. At a later stage of this project, the coefficients will be adjusted (ranging e.g., from 1 to 5) to reflect the particularities and different aspects or needs of the smart sustainable islands.

\begin{tabular}{|c|c|}
\hline Sub-Dimension & Indicator's Measured Values \\
\hline \multicolumn{2}{|r|}{ ICT \& Economy } \\
\hline Network Facilities & $\begin{array}{l}\text { Fixed broadband subscribers (per } 100 \text { inhabit.) - } \\
\text { Wirless/Mob/3G+ subscribers (per } 100 \text { inhabit.) - Intl. B/W per } \\
\text { Internet user (bps) - \% of Households with Internet access - \% of } \\
\text { Households with a Computer - Coverage rate of next-G networks }\end{array}$ \\
\hline Information Facilities & $\begin{array}{l}\% \text { of enterprizes providing e-services - Proportion of business } \\
\text { based on Cloud - Proportion of business based on GIS } \\
\text { Island Coverage \% by digital Cadasters }\end{array}$ \\
\hline $\begin{array}{l}\text { Innovation \& } \\
\text { Opportunities }\end{array}$ & $\begin{array}{l}\text { Ease of starting a business (days) - Teleworking penetration (\%) } \\
\text { - Work Scheduling flexibility (\%) } \\
\% \text { of part-time employment - Formal/informal employment ratio } \\
\text { - \% of R\&D expenditure }\end{array}$ \\
\hline $\begin{array}{l}\text { Economy \& } \\
\text { Production }\end{array}$ & $\begin{array}{l}\text { Inflation (\%) - Loan payout rate - \% of e-Commerce transaction } \\
\text { amount - Household Income/consumption ratio - Island } \\
\text { Export/import of goods ratio } \\
\text { Importance as tourist location (total sights, overnights) - } \\
\text { Overnights per year per resident - International tourists (arrivals } \\
\text { per resid.) }\end{array}$ \\
\hline \multicolumn{2}{|r|}{ Resource Sustainability } \\
\hline Energy & $\begin{array}{l}\text { ICT use in Power Grid resilience - Average length of el. } \\
\text { iteruptions (hr/day) - Civilian electricity usage improvem. - } \\
\text { Industrial electricity usage improvem. - Heat supply systems } \\
\text { usage improvem. - \% of Renewable energy sources on total } \\
\text { consumption }\end{array}$ \\
\hline Water & $\begin{array}{l}\text { Water quality \% - Continuity of water service (hr/day) - \% } \\
\text { households connected to water service - Water treatment } \\
\text { proc/level improvement - \% of Water desalination - \% of Water } \\
\text { recycling - \% of popul. served by water collection - Domestic } \\
\text { water consumption (lt/day) - Industrial water usage improvement } \\
\text { - Years of positive water balance }\end{array}$ \\
\hline $\begin{array}{l}\text { Environment } \\
\text { Monitoring }\end{array}$ & $\begin{array}{l}\text { Percentage \% of ICT means used for: } \\
\text { - Water resource protection, - Flood control monitoring } \\
\text { - Water pollution control, - Air pollution/CO2 monitoring, - } \\
\text { Noise pollution monitoring, - Toxic substances monitoring, - } \\
\text { Solid Waste Disposal }\end{array}$ \\
\hline $\begin{array}{l}\text { Natural } \\
\text { Resources }\end{array}$ & $\begin{array}{l}\text { Fuel usage improvement - Natural Gas usage improvement - } \\
\text { Rare/noble metal usage improvement }\end{array}$ \\
\hline \multicolumn{2}{|r|}{ Infrastructure } \\
\hline Building & $\begin{array}{l}\text { Application level of energy saving techn. in public buildings - \% } \\
\text { of public buildings with integrated technologies - Proportion of } \\
\text { smart home automation adoption - Proportion of smart materials } \\
\text { used }\end{array}$ \\
\hline Transport & $\begin{array}{l}\text { Road infrastructures (km/100k pop.) - Airport, Port } \\
\text { infrastructures (passenger rates) - Air/Sea/Coastal Lines No. \& } \\
\text { freq., Coverage of road sensing terminals installation - Coverage } \\
\text { of parking guidance systems - Coverage of electr.bus bulletin } \\
\text { board (ITS) }\end{array}$ \\
\hline Sanitation & $\begin{array}{l}\text { \% households connected to sewer system - ICT use in Sewage } \\
\text { discharge managem. - ICT use in Waste water recycling }\end{array}$ \\
\hline Municipal networks & $\begin{array}{l}\text { ICT use in Drainage system management - ICT use in Lighting } \\
\text { system management - ICT use in Cas system management - ICT } \\
\text { use in Electicity supply system man. - Water saving smart } \\
\text { metering - ICT use in underground pipelines improved } \\
\text { administration }\end{array}$ \\
\hline \multicolumn{2}{|r|}{ Quality of life } \\
\hline $\begin{array}{l}\text { Convenience } \\
\& \text { Comfort }\end{array}$ & $\begin{array}{l}\text { Satisfaction with online services - Convenience of government } \\
\text { services - Convenience of traffic info \& admin - Satisfaction } \\
\text { with public transport quality - Satisfaction with crime prevention } \\
\& \text { security - Satisfaction with disaster countermeasures - } \\
\text { Satisfaction with food/drug safety monitoring - Satisfaction with } \\
\text { housing conditions - Convenience of medical care - } \\
\text { Convenience of education access - Proof against risk of poverty - } \\
\text { Recreational area per 100k popul. - Average living area per } \\
\text { inhabitant }\end{array}$ \\
\hline $\begin{array}{l}\text { Security } \\
\& \text { Safety }\end{array}$ & $\begin{array}{l}\text { Accident prediction ratio - ICT use for disaster prevention - } \\
\text { Penetration of city video surveillance - No. of police officers per } \\
100 \mathrm{k} \text { popul. - No. of crimes per } 100 \mathrm{k} \text { popul. }\end{array}$ \\
\hline $\begin{array}{l}\text { Health } \\
\text { Care }\end{array}$ & $\begin{array}{l}\text { No. of hospital beds per 100k popul. - No. of physitians per 100k } \\
\text { popul. - Life expectancy improvement - Under- } 5 \text { mortality rate - } \\
\% \text { of electr. health records archiving - Usage rate of electr. } \\
\text { medical records - Coverage rate of household e-Health services }\end{array}$ \\
\hline Education & $\begin{array}{l}\text { Literacy (\% prim/sec/tert. enrolment) - Childrens journeys } \\
\text { to/from school - Penetration of e-Learning system }\end{array}$ \\
\hline \multicolumn{2}{|r|}{ Society } \\
\hline $\begin{array}{l}\text { Openness \& public } \\
\text { partitip. }\end{array}$ & $\begin{array}{l}\text { On-line civic engagement/partitipation \% - Feasibility of } \\
\text { appealing on-line }\end{array}$ \\
\hline $\begin{array}{l}\text { Social sustain. } \\
\text { \& equity }\end{array}$ & $\begin{array}{l}\text { Gini coefficient of income inequality - Gender ratio of access to } \\
\text { services - Age \& Disab. ratios of access to services - Social } \\
\text { insurance coverage improvem. }\end{array}$ \\
\hline $\begin{array}{l}\text { Governance } \\
\text { sustainability }\end{array}$ & $\begin{array}{l}\text { Appliance of smart community services - Penetration rate of } \\
\text { government on-line services - Penetration rate of government } \\
\text { open information - Digital access to urban planning \& budget } \\
\text { document }\end{array}$ \\
\hline
\end{tabular}

Table 3. Major Indicators and Metrics of the proposed KPI scheme for Smart Sustainable Islands Index $\left(\mathrm{S}^{2} \mathrm{I}^{2}\right)$ 


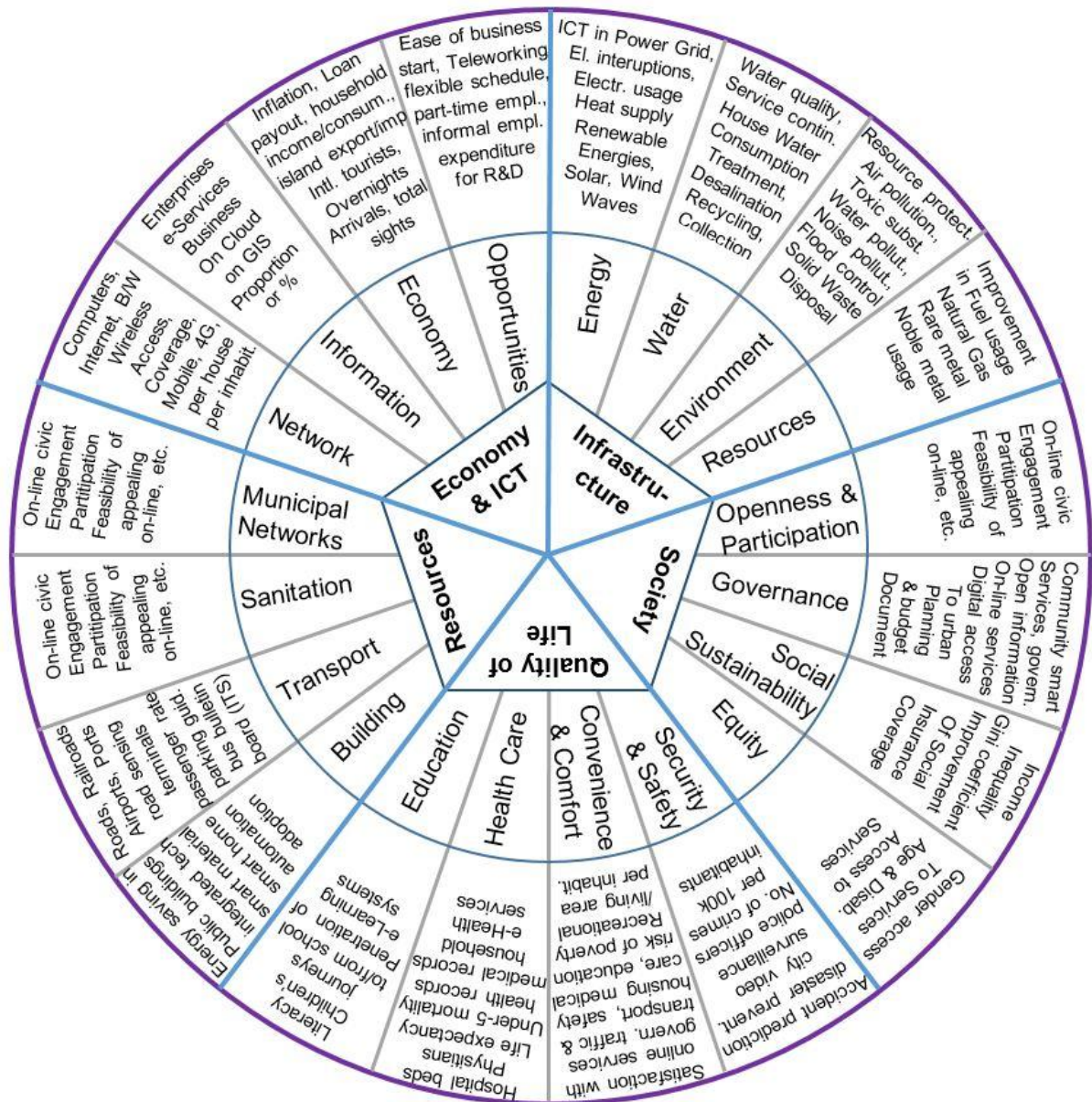

Figure 2: A wheel representation of the proposed $\mathrm{S}^{2} \mathrm{I}^{2}$ scheme.

\section{A EUROPEAN ISLANDS' SMARTIFICATION AND SUSTAINABILITY OBSERVATORY}

The full version of the island smartification roadmap is expected by the end of September 2017. A demo site/portal already exists in https://socratesteiath.wixsite.com/smart-greenislands (Figure 3).

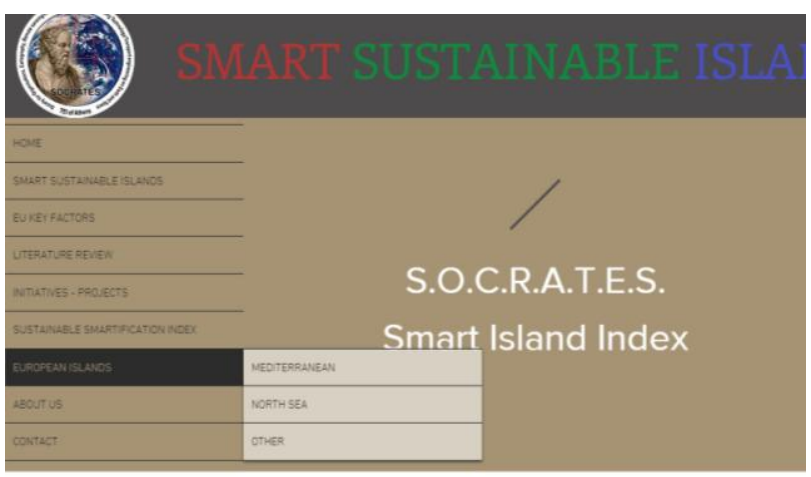

$$
\begin{aligned}
& \text { The creation of an island smartification and } \\
& \text { sustainabily's index is one of the target of our project. }
\end{aligned}
$$

Figure 3: The SOCRATES site for smart sustainable European islands \& the smartification and sustainability Island's index (SOCRATES $S^{2} \mathrm{I}^{2}$ ).

Our targets are the following: a) the presentation of possible sustainable smartification actions in the frame of an holistic master plan in insular municipalities (islands) b) the exchange of experience and knowledge in the field directly from island to island and the presentation of sustainable smartification examples c) the collection and publication of meta-data and meta-information about smart and sustainable actions in islands as well as tools, concepts and procedures d) the indexation of all islands in order to classify their achievements in the smartification's and sustainability's fields with quantitative and qualitative manner. The experience from similar efforts will also be taken into consideration (ITU, 2016) (TUW, 2017). As a first step, we will start with the Greek insular municipalities which are 95 in a total of 325 municipalities. (https://www.google.com/fusiontables/DataSource?docid=1 vyl YqlwVehy_iQeOwCypBtbZwmJCzZbn1i19vxJK\#map:id=3). At a next stage, we will continue with the European islands of the EU "smart island initiative" (http://www. smartislandsinitiative.eu/gr/members_map.php) (Figure 4) and at a third step we will continue with all European Islands (https://en.wikipedia.org/wiki/List_of_European_islands_by_ar ea, andhttps://europeansmallislands.com/members/).

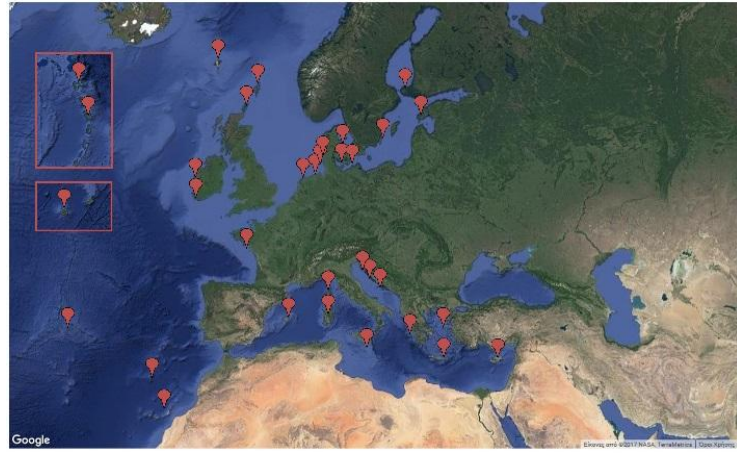

Figure 4: The EU initiative "smart islands" islands 


\section{MUNICIPALITY OF PAROS / MUNICIPALITY OF ANTIPAROS AND S.O.C.R.A.T.E.S.: A FIRST STEP TOWARDS A SMART COLLABORATION}

The Municipalities of Paros (Figure 5) and Antiparos in the frame of the scientific collaboration agreement signed with the Research Laboratory S.O.C.R.A.T.E.S. will test the portal (Figure 3) and the island smartification's and sustainability's guide "Towards to a smart sustainable Island: A guide for actions" and they will receive a first proposal for priority smartification's and sustainability's actions in their territory.

As a start point for the municipality of Paros and Antiparos we propose the following:

A) The creation of two municipal GIS covering the entire islands combined with Paperless Office Environment smart applications for the local government, citizens and visitors. One important aspect of a Smart Sustainable Island is the elimination of paper use in office environments. According to various researches, the increase of the number of employees in an organization increases the probability of the loss of a document or the ability to retrieve it when it is required, while $80 \%$ of a manager's time is spent searching for documents. It is very important for an organization that every employee is able to find a document whenever they need it, without delays or errors. The first step is to digitize existing paper documents and then process them using OCR, data capture, classification and manual indexing software in order to create searchable digital files that can be stored in a document management system where specific information or text can be retrieved in a few seconds. When the digitization process is finished, all the digitized paper documents can be recycled. For the digitization, appropriate scanners, optimally configured to produce exact copies of the original documents, can be used. Then the digital copies of the documents can be processed by special software based on OCR technology in order to: a) Automatically classify documents to specific predefined categories b) Automatically capture specific fields from each document type in case the documents' types and layouts are known c) Assist users to index documents without typing (one click indexing) in case of documents with no predefined layout and d) Produce searchable files (e.g. PDF) by recognizing all instances of text in each page (full text retrieval). The digitization process also concerns the cartographic and topographic data and maps. For handwritten documents, manual indexing software can be used in order to facilitate their search. The next step is to create mechanisms that can create digital born documents and to process all the incoming documents as mentioned above. The proposed system could handle the following:- Incoming, outgoing and internal correspondence,- Organized keeping, handling and monitoring of categorized folders of projects and customers,- Invoices, receipts etc. and financial procedures in general,- Legal cases,Monitoring of ISO procedures, -Keeping of minutes of meetings. The adoption of a paperless office environment combine with a GIS environment will reorganize and simplify the internal procedures, accelerate the filing, retrieval and processing of documents and related information, minimize possible errors, provide tools for monitoring documents and procedures, eliminate the use of paper, minimize the operation cost of an office and the required space for storing a physical archive. Finally, when all the documents are stored in a document management system, statistical data and custom reports can be generated in order to optimize the operation of an office.

B) Development of a number of applications with drones in the fields of cartography (cartographic coverage of both islands), waste site surveillance (in Paros and Antiparos), spatial touristic information development and flight simulation over the island (Figure 5). We believe that the Unmanned Aerial Systems (UAS) has a potential role to play in a smart island. Today high spatial resolution data can be achieved with rapid and low cost UAS that can produce mid-large scale orthophoto maps and 3D Digital Surface Models (DSM) of $200 \mathrm{~km}^{2}$ (equal to the area of Paros island) within few days. Multispectral mosaics of high spatial resolution of down to $3 \mathrm{~cm} / \mathrm{px}$ can provide us, apart from a detailed visualization, also useful data, and DSMs can offer accurate measurements of the changes of the surface. Those data can be used for many geospatial analysis applications (besides the proposed above) such as volumetric measurements, water resources management, vegetation and water stress indices in agriculture and flora, infrastructure development, urban spatial planning, waste management (Figure 5) etc. The multi-operability value that characterizes these big data can be proven an additional tool to the local administrator's Decision Support Systems integrated in municipal GIS, on an island's scale. Through the municipal GIS and thematic mapping we can spatially distribute the different subjects of interest and directly link them to sensors and other 'smart' tools for improving the quality of life within an intelligent island. Apart from the great advantage of the high spatial resolution, the importance of the high temporal resolution also needs to be mentioned. In the constantly alternating environment of an island, especially in the Mediterranean, the seasonal changes of climate are more perceptible, and their effect on the landscape, on the natural resources and generally on the environment is more intense. Consequently, it is observed that vital sectors of the economy such as tourism and agriculture are entirely connected to these periodic variations. Thus, the possibility to function low cost UASs at analyst's will, repeatedly and in a studied periodic pace, and the upcoming time series data produced, can allow the analyst to assess the changes in terms of topography, land uses etc, in ever-changing sensitive ecosystems, such as coastal wetlands. This analysis could lead to a more clear understanding of the solid links between the environment and the local economy and their behavior

C) Telemedicine Applications. A step towards the smartification of an island could be the use of an integrated telemedicine system that would give the opportunity for habitants of distant locations, with no access to an equipped health care facility, to have their medical measurements data monitored by medical personnel situated at a distant hospital. The proposed health monitoring system (Vlissidis, 2017) is consisted of a portable device which includes various medical sensor modules for performing real-time measurements (e.g. pulse rate, blood oxygen saturation, respiration rate, body temperature, electrocardiogram, non-invasive blood pressure) and appropriate microprocessors in order to process and multiplex the sensors' data and to control their operation. Various probes attached to the patient can be used in order to perform the measurements. The medical device is connected to an interface e.g. (RS232 or USB) of a personal computer with internet access, where an application constantly monitors the input port, decodes the incoming data frames and inserts the measurement data and various information that concern the device and the measurement in a remote database server. Another database client application with a graphical user interface hosted in a personal computer or a mobile device depicts the medical measurements and informs the distant medical personnel about a potential health problem. Paros and Antiparos may have an important support in health care using smart applications of the field of telemedicine. 


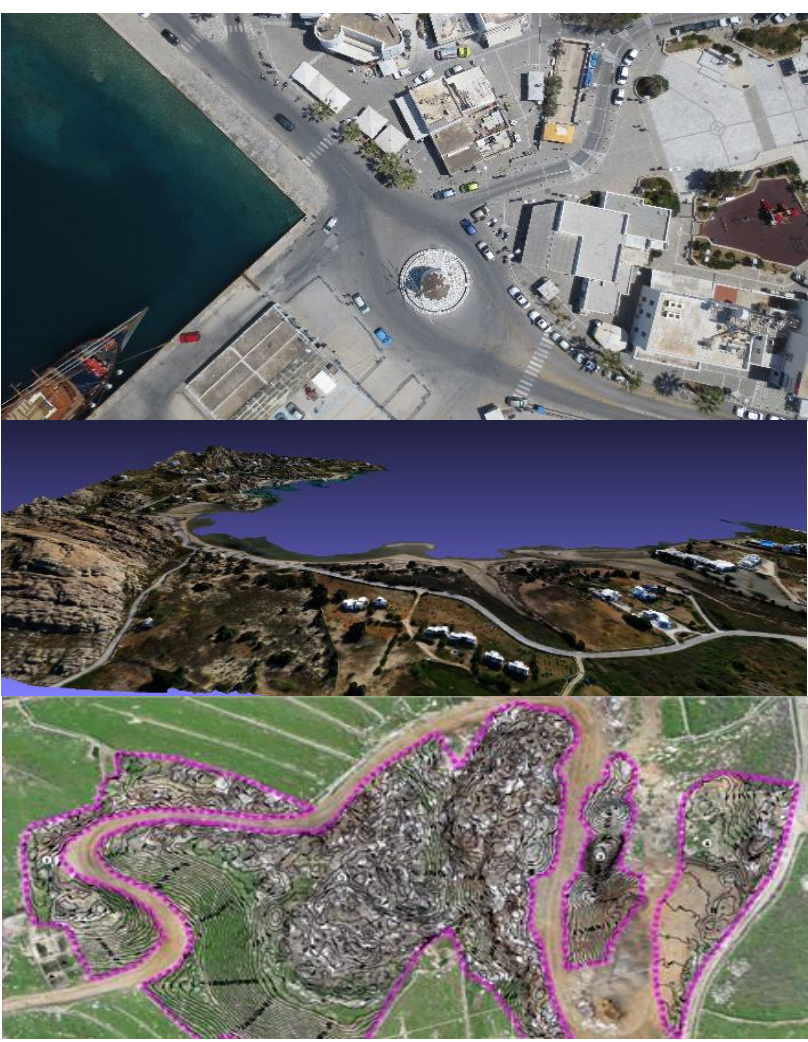

Figure 5: Drone's data for the municipal proposal preparation concerning the municipal GIS and smart applications.

D) Coastal transport. The coastal connection of Paros and Antiparos with Athens/Piraeus and other cities in the mainland as also with other islands, in the frame of a holistic and integrated coastal transport system, still an acute problem not only for those two insular municipalities. The CO.TR.I.S. (COstal Transport Information System) give a number of solutions but the operational use of the system lack of financial resources. Nevertheless, the improvement of the system with the support of the two municipalities still one of the most advanced smart applications in the key factor "transport". Other applications such as the electric ferries (http://e-ferryproject.eu/) still under consideration in the final proposal.

E) Energy. The complete autonomy of the islands in terms of energy must be one of the strategic targets of the two islands. Despite the fact that some wind generators and solar panels already exist, both islands lack of a strategic energy master plan with long vision. GIS, relative data, spatial analysis and presentation of innovative smart solutions for renewable energy sources with respect to natural environment of the islands and the wellbeing of its habitants will be part of the final proposal to the two municipalities.

\section{CONCLUSIONS AND PERSPECTIVES}

A critical analysis of the content and meaning of two terms ("smart sustainable cities" and "smart sustainable islands") introduced recently in the relative literature has been presented. The aim of the analysis was the creation of a solid theoretical basis for the development of a methodological framework of concepts and actions, in a form of a manual and actions guide, towards the smartification and sustainability of the islands. The principles of this kind of "master plan" (under development) divided in thematic sectors (key factors) which concern the insular municipalities is presented in a specific portal developed in the same framework together with relative resources and smart applications examples. The creation of a new smartification's and sustainability's island's index was another part of our paper (the SOCRATES $S^{2} I^{2}$ index). The number of index and parameters that must be used for each island may be different. This number could depend of the island's surface, the population, the number of coastal lines etc. In any case the question still holds: how many parameters/indices must be used in order to compare the level of smartification between islands and between cities? Must this number be the same for all kind of island and all kind of cities? This analysis is included in a future step of our research. The first results of our index application in a number of Greek islands will be presented in the above mentioned portal, giving a first classification according to the degree of their smartification's and sustainability's actions. Finally, we presented some proposals of possible actions in the insular municipalities of Paros and Antiparos - Greece concerning their sustainability and smartification process following the structure of the proposed "Actions Guide for Island Smartification and Sustainability".

\section{REFERENCES}

Albino V., et al, 2015. Smart Cities: Definitions, Dimensions, Performance and Initiatives. Journal of Urban Technology, Vol 22, No 1-3.

AMK, 2016. Smart Green Island Makeathon presentation, https://www.youtube.com/watch?v=sELbSs_tKEs, http://amkgroup.com/en/content/smart_green_island_makeathon (30 Mar 2017)

BD, 2017. Smart City - Definition. BusinessDictionary, http://www.businessdictionary.com/definition/smart-city.html, (30 Mar 2017)

Bertacchini, Y., coord. 2007. Intelligence territoriale. Le Territoire dans tous ses états. Collection Les ETIC, Toulon, Presses Technologiques

BGC, 2016. The Blue-Green Cities Research Project, Univ. of Nottingham, Feb 2016, www.bluegreencities.ac.uk, (30 Mar 2017)

Chong, Bruce et al. 2014. From Smart to Smart-Green-Resilient City planning. Annual China Urban Planning Conference, Hai Kou, Hainan, 2014,

CNR 2016, Smart Island - Smart Archipelagos Project, CNR IIA, Italy, http://www.smartisland.eu/en/ (5)

DBIS, 2013. Smart Cities. background paper Oct. 2013, Department for Business, Innovation and Skills, UK, www.gov.uk (30 Mar 2017)

Deign J., 2016. First Smart Cities and now Smart Islands. Cisco network, Jan 2016, https://newsroom.cisco.com/featurecontent?articleId=1735451 (30 Mar 2017)

Di Staso, U., Magliocchetti, D. and De Amicis, R. 2014. SmartIslands: Enhancing User Experience for Mediterranean Islands for Tourism Support. in A. Marcus (Ed.): DUXU 2014, Part II, LNCS 8518, Springer International Publishing Switzerland pp. 223-233.

DNVGL, 2017. Smart Green Cities - A plan for the future with stepping stones to get there. www.dnvgl.com/energy/themes/smart-green-cities.html, Mar 2017)

Efthymiopoulos I. et al., 2016. Smart Islands Projects and Strategies. Issued from the 1st European Smart Islands Forum, June 2016, Athens, Greece, Friedrich Ebert Stiftung. http://library.fes.de/pdf-files/bueros/athen/12860.pdf $\quad(30$ Mar 2017)

EU, 2015. Smart Islands Project - EESC initiative. http://www.eesc.europa.eu/?i=portal.en.smart-islands-missions (30 Mar 2017) 
EU, 2017. Smart Islands Initiative - Smart Islands Event: Creating New Pathways for EU islands. 28 Mar 2017, http://www.smartislandsinitiative.eu/en/index.php $\quad(30 \quad$ Mar 2017)

GISIG, 2014. Smart Webservices for Mediterranean Islands, ICT-PSP Grant 2011-14, http://www.gisig.eu/smart-islands-2/ (30 Mar 2017)

IEEE, 2017. Smart Cities "About", http://smartcities.ieee.org/about, (30 Mar 2017).

ITU, 2015. "Key performance indicators definitions for smart sustainable cities", Focus Group on Smart Sustainable Cities FG-SSC, International Telecommunication Union Telecommunication standardization sector ITU-T, Technical Report, 02/2015.

ITU, 2016. The ICT Development Index (IDI): Conceptual framework and methodology,www.itu.int/en/ITUD/Statistics/Pages/publications/mis2016/methodology.aspx, \& http://www.itu.int/net4/ITU-D/idi/2016/ (30 Mar 2017)

Lehmann, S. 2010. Green urbanism: formulating a series of holistic principles. S.A.P.I.EN.S. 3 (2)

Manville, e.a. 2014. Mapping Smart Cities in the EU, Policy Department Economic and Scientific Policy, European Parliament, Brussels.

Musa Sam, 2016. Smart City Roadmap. Avail.at: www.academia.edu/21181336/Smart_City_Roadmap.

NYC, 2015. Building A Smart+Equitable City. New York City Mayor's Office of Tech+Innovation, Sep. 2015.

Sang Ziqin, Dr., 2013. Smart city in China. 8th ITU Symposium on ICT, Environment and Climate Change, Turin, Italy, 6-7 May 2013.

Sanseverino, E.R. and Sanseverino, R.R. and Vaccaro, V., 2016. Smart Cities Atlas: Western and Eastern Intelligent Communities. Springer Tracts in Civil Engineering, Springer International Publishing

Sarwant S., 2014. Article on Forbes - June 19 "Smart Cities -- A \$1.5 Trillion Market Opportunity" (30 Mar 2017)

Stetter, 2016. Project Smart Green Island, https://www.itq.de/wp-content/uploads/2017/01/Dr-

Stetter_ITQ_Project_Smart_Green_Island.pdf),

TUW, 2007. Smart cities Ranking of European medium-sized cities. European smart cities Project Report, TU Wien, Vienna University of Technology, Oct. 2007, Avail.at: http://www.smart-

cities.eu/download/smart_cities_final_report.pdf(30 Mar 2017) UDMS, 2017. Urban Data Management Society, 2nd Intl. Conf. on Smart Data and Smart Cities, website, http://ing.pue.itesm.mx/udms2017 (30 Mar 2017).

Vlissidis N., Leonidas F., Giovanis C., Marinos D., Aidinis K., Vassilopoulos C., Pagiatakis G., Schmitt N., Pistner T., and Klaue J., 2017. A sensor monitoring system for telemedicine, safety and security applications. Intl J. Electronics Vol 104 (2) Winters J.V., 2011. Why are Smart Cities Growing? Who moves and who Stays? Journal of Regional Science, 51(2), pp 253-270

Woodrow Clark II, Grant Cooke, 2016. Smart Green Cities: Toward a Carbon Neutral World, Routledge 